\title{
Discussion on Innovative Education of College Students E - business Innovation
}

\author{
Mengqing Feng ${ }^{1,2, a}$, \\ ${ }^{1}$ School of Information Engineering, Zhengzhou University of Industrial Technology, \\ Zhengzhou Henan 451150, PR China \\ ${ }^{2}$ Machine learning and Data researching Institute, Zhengzhou University of Industrial Technology, \\ Zhengzhou Henan 451150, PR China \\ a903901419@qq.com
}

\begin{abstract}
Keywords: College student entrepreneurship; E-commerce innovation education; Education mode; Education platform
\end{abstract}

\begin{abstract}
With the rapid development of e-commerce in our country, many college students regard e-commerce as their preferred business model for personal entrepreneurship. Under the new situation, the e-commerce education for undergraduates should be strengthened. The emphasis is to strengthen the "three education" such as the popularization education of entrepreneurial awareness of e-commerce, the specialized education of entrepreneurial skills and the personalized education of undertaking actual combat; the establishment of "Internet + E-business innovation education "platform for learning, entrepreneurs, schools, families, businesses and social communication platform, public support platforms such as" three platforms "to build schools, families and all sectors of society's three-dimensional ecological help education system.
\end{abstract}

\section{Introduction}

Under the current global economic integration and the slowdown of domestic economic growth, our government advocates "public entrepreneurship and innovation". Undergraduates are the new force in entrepreneurship and innovation, and are the most innovative and entrepreneurial potential groups. More and more college students are involved in starting a business. Entrepreneurship and innovation have become the "new engines" driving China's economic growth. The 39th Statistical Report on the State of Internet Development in China shows that as of December 2016, the number of netizens in China reached 731 million, of which the proportion of online shopping users to Internet users was $63.80 \%$ and the scale reached 467 million. According to statistics, in 2016, the online retail sales in China reached 5.15 trillion yuan, an increase of $26.20 \%$ over the previous year. From these data, we can see that both the scale of Internet users and the market capacity of online shopping have shown that there is plenty of room for domestic e-commerce market and there is a great way for e-business [1-4] to start up. At the same time, due to the relatively low entry threshold of e-commerce, college students are very familiar with the application of e-commerce, e-commerce will undoubtedly become the ideal choice for college students to start a business. However, entrepreneurship, after all, is different from the daily learning of college students, e-commerce entrepreneurs need to have the general qualities of traditional entrepreneurs, but also have the ability to deal with information and application of Internet conditions. Therefore, in order to improve the success rate of college students to start e-commerce, to help college students achieve the ideal of e-commerce business, to strengthen e-commerce entrepreneurship education is particularly important.

\section{The Present Situation of the College Students E-Commerce Business Innovation Education}

In recent years, innovative entrepreneurship education in colleges and universities to strengthen[5-8], positive progress has been made, to improve the quality of higher education and promote students' all-round development, to promote graduates employment, entrepreneurship 
services play an important role in national modernization construction. Many scholars have made great achievements in the research of university students' innovation and entrepreneurship education. I know net (http://www.cnki.net) in China in accordance with the "title", "subject" and "key words" search, input "entrepreneurial education" to retrieve literature quantity results respectively is $19,374,12,184$ and 879;And input "e-commerce venture education" retrieval number results were only 38 references 1 , article 13 and article, this is more than only a few articles for e-commerce business case studies, or research on e-commerce professional entrepreneurial talent cultivation, among them, in accordance with the "key words" retrieve only 1 piece of literature, and is the author's research results published in 2012. The above data can be clearly seen that the results of education research are very small, which is not commensurate with the current development of domestic e-commerce.

Through the above domestic e-commerce venture education present situation, can be found that e-commerce venture education has brought to the attention of the many higher vocational colleges and ordinary undergraduate course colleges and universities, entrepreneurial talent cultivation to the electronic commerce has made many beneficial experience. These e-commerce business education, however, the vast majority is for the cultivation of professional talents, e-commerce and e-commerce for non-native e-commerce professional college students entrepreneurship education is very few, or the students to participate in some famous venture speech "e-commerce" "e-commerce business innovation competition" and other activities are also summed up in e-business entrepreneurship education. In general, the education mechanism of college students' e-commerce entrepreneurship innovation is not sound enough, and the basis of education is still weak.

\section{College students' e-commerce entrepreneurship innovation education's "three - way" mode}

With the concept of mass entrepreneurship and innovation in China, e-commerce has become an important means to implement "Internet plus[9-10]".With the rapid development of future Internet third-party e-commerce platforms, community e-commerce, rural e-commerce, wechat business and cross-border e-commerce, it will provide college students with more opportunities to innovate and start their own businesses. But entrepreneurs should not only have the electronic commerce, electronic commerce and related profession knowledge, what more need to be engaged in the related knowledge and skills of the industry, at the same time, also need to have strong practical ability, good communication skills, flexible strain capacity, good psychological quality, etc. Therefore, the e-commerce business innovation education of colleges and universities should readjust the teaching mode, from the perspective of cultivating compound applied innovative entrepreneurial talents, pay more attention to the cultivation of student's e-commerce business innovation ability. To this end, the author combining with the characteristics of e-commerce business and puts forward the electronic commerce business innovation education "three" education mode, help those college students with e-commerce business wishes to realize individual entrepreneurial dream.

Popularization of e-commerce entrepreneurship awareness education. Since e-commerce entrepreneurship has the advantage of "low start-up threshold, low technical requirements and relatively low risk of investment". Compared with the real startup, the risk of college students' e-business venture is not too great. However, just enjoy the benefits of e-commerce, the vast majority of college students rarely consider their own e-commerce business, or have e-commerce business mind, however, since you know nothing about business, and often are not familiar with computer and network application, entrepreneurship dream soon disappeared in the midst of confusion. E-business entrepreneurship education, therefore, the first step is to conduct e-commerce venture consciousness education universalization, can carry out "taobao expert lectures" e-commerce venture successful speech "and" e-commerce competition "and other activities cause their business interests, you can open the" entrepreneurial base "" e-commerce business courses such as basic knowledge popularization of e-commerce business, the main purpose is to stimulate the entrepreneurial passion, e-commerce make their e-commerce venture consciousness get 
distillation.

Firstly, the platform can be used to simulate training software such as "entrepreneurial star", which is developed by kingdee company.Cultivate the management of entrepreneurs and the quality of teamwork, so that entrepreneurs have a more intuitive understanding of entrepreneurship. In the "star of entrepreneurship", each group, a production manufacturing enterprises, the request must be within the prescribed period of time, using the power of the team, based on enterprise according to the analysis of the real-time data and competitors, to formulate the management of enterprise operational decision-making, consisting of a virtual enterprise to compete with other students, and strive to make the enterprise performance to achieve the best, make the business enterprise can in the fierce market competition growing step by step. These business decisions involve the enterprise's strategy, marketing, finance, production, research and development, etc. Through this platform for simulation training, can let students better understand the team cooperation, communication skills and execution in the importance of the decision, at the same time, also can find their own entrepreneurship defects, motivate them to enter into further business professional knowledge learning process.

Secondly ,take advantage of the "SIYB" series of courses that have been used in China at present, and carry out a complete business plan training for participating entrepreneurs. Main content includes: the entrepreneur evaluation, project design and selection of venture project, product, customer and competitor analysis, enterprise personnel organization and business aspects of the laws and regulations, predict start-up capital demand, profit plan, project feasibility analysis and actual application, start your own enterprise and so on. Teaching can adopt in the process of scene simulation, case discussion, group discussion and sharing, business interviews, group game, group tasks, business and brainstorming, and other forms of teaching methods, giving the trainee a good education atmosphere, enable entrepreneurs trained to have the basic knowledge, to create a real business to basic cope with the upcoming e-commerce venture project, preliminary learn how to manage and operate their own businesses.

Thirdly, Conduct a team e-business venture drill. Each team consists of 3 a 5 students, can cooperate with outside the enterprise, use of third-party e-commerce platform, open online stores sell cooperative enterprises to provide products, according to the stipulated time performance ranking and the profitability of each team members, and all entrepreneurs to store operation problems appeared in the process of review and participation for students to have a deeper understanding of electronic commerce.

Personalized education for e-commerce entrepreneurship. E-commerce business education college students is not the result of the single business knowledge popularization, but after entrepreneurship education, training, trainees can real to implement their business plan. Therefore, it is more important to personalize education tutoring when college students enter the actual combat stage of e-commerce. From the feedback of college students' entrepreneurship in recent years, the success rate of college students is not high, and the problems facing startups are also prominent. According to a survey by the ministry of human resources, the success rate of college students in the past is only $2.4 \%$. According to the China college employment report, more than half of the graduates who started their own businesses after graduating six months later quit their businesses. According to research data from institutions such as the Chinese academy of social sciences, even in provinces with better entrepreneurial environments such as zhejiang, the success rate of college students is only about 5\%.Compared with western data, the success rate of college students in foreign countries is about $20 \%$, and the difference between them is huge. Many college students entrepreneurial projects, initial stage to their own independent processing all kinds of affairs, this time because entrepreneurs lack of social practice experience, poor mental capacity, knowledge update couldn't keep up with business requirements, if the venture is not determined, it is easy to cause failure. At this time, the school support strength to the entrepreneurial college students are important influencing factors. Therefore, the electronic business start-ups personalized counseling education, mainly for entrepreneurs can timely attention, some difficult problems for entrepreneurial students plan plan, finance, causes the student to e-commerce business would be 
able to step back on track.

\section{Some Suggestions on the education of college students' e-business entrepreneurship and innovation under the new situation}

Establish a learning platform for "Internet + e-business innovation education" In July 2015, promulgated by the state council "about promoting action guidance for" Internet + "pointed out that" Internet + "is the innovation on the Internet with the depth of the economic society in various fields, to promote technological progress, improve efficiency and organizational change, and promote the transformation and upgrading of industry, and construct the new form of economic and social development. Combination of Internet and education industry, has a broad prospect and infinite potential and advantageous to realize the innovation and development of education, reconstructing education ecological system, realize the innovation in teaching environment, teaching management, course system, teaching, learning, innovation, etc. "Internet + education" will bring new features to cultivate talents in colleges and universities teaching space, education supply mode from the traditional "one school, a classroom, a teacher, a group of students" teaching mode to "a network, a terminal, tens of thousands of students, school teachers choose" education service transfer form. This is not subject to regional and time limit of education form more suitable for college students entrepreneurial learning needs, e-business entrepreneurship education and "Internet +" fusion, establishing entrepreneurs learning platform is just to the right time.

Establish a communication platform between entrepreneurs, schools and families. According to the "90 after college students entrepreneurial factors", according to the survey data in the college students' entrepreneurial influencing factors (individual factors, family factors, school factors, social factors and other factors), the factors of effect on entrepreneurship in the top three, respectively is family support, financial support and school support. As can be seen from this, the university student e-commerce entrepreneurship innovation education, not only includes the school's professional knowledge of education, but also includes the family of entrepreneurs education, emotional communication and social experience teaching. Built, therefore, to recognize the communication platform between and among schools, entrepreneurs and families is particularly necessary, can use WeChat, QQ instant messaging tools such as structures, entrepreneurial community communication platform, through which group of schools can timely release information about the college students' entrepreneurship and entrepreneurs can contact at any time to guide teachers and parents, thorny problems can in time to ask for help, parents also can know your child's ideas, entrepreneurial resistance, and entrepreneurs to share their rich social experience. With the guidance of school teachers and strong support from families, entrepreneurs are no longer alone, and their success rate will increase greatly.

Establishment of a platform for the support of schools, enterprises and societies. In 2015, promulgated by the state council "about to speed up the building masses entrepreneurship guidance of peoples innovation supporting platform, points out that" at present, the global share of rapid economic growth, based on the way of the booming business innovation, such as the Internet, gen, crowdsourcing, all your helps, such as the raise public entrepreneurship peoples innovation support platform for rapid development...", among them, the hand refers to huizhong can help business, support, enterprise support by the government and public institutions such as mutual aid, personal $\mathrm{HuFu}$ a variety of ways, for small micro enterprises and entrepreneurs growth and build good ecological entrepreneurial innovation and development. It can be seen that all college students entrepreneurial innovation education can't rely on school, you must make full use of good government policies, actively seeking public welfare institutions support, enterprise support aid, to entrepreneurs to create a good ecological environment, innovation of undertaking small micro enterprises and entrepreneurs to get fast growth.(1) universities should strengthen the construction of university science and technology parks, college students' entrepreneurship parks, entrepreneurial incubators and small and micro businesses. Base as entrepreneurial platform support college students entrepreneurship education practice, on the other hand, universities should actively organize students to participate in the contest of national college students' innovative undertaking, 
support for students to set up innovation business association and the club, club, regularly carry out innovation entrepreneurship lectures BBS, entrepreneurship practice activities, to give college students entrepreneurship all-round education service support;(2) speed up the opening and sharing of public scientific and technological resources and information resources. We should improve the service capacity of various public welfare institutions, innovation platforms and bases, and reduce the cost of mass entrepreneurship and innovation. Encourage industry associations, industry associations and other industry organizations and third-party service agencies to strengthen support for small and micro businesses and entrepreneurs;(3) encourage enterprises to share the support. Large enterprises as the mainstay of industrial structure adjustment and the old and the new kinetic energy conversion, in the new normal to give full play to the advantage of capital, technology, talent, to promote their own innovation at the same time, through production collaboration, open platform, Shared resources, such as open standards, driving the development of upstream and downstream small micro enterprises and entrepreneurs. Enterprises with the conditions can initiate or participate in the establishment of public welfare venture funds according to law, support the start-up financing of college students, carry out the training and guidance of college students, and fulfill corporate social responsibility;(4) we should strongly support public support. For example, various mutual support platforms, such as open source community, developer community, resource sharing platform, donation platform and entrepreneurship salon, can be helpful to college students' e-business innovation.

\section{References}

[1] Zhang Y, Bian J, Zhu W. Trust fraud: A crucial challenge for China's e-commerce market[J]. Electronic Commerce Research \& Applications, 2013, 12(5):299-308.

[2] Ren L, Zhao Y. Interdisciplinary Model of Fashion Marketing and E-Commerce Education[J]. Journal of Zhejiang Sci-Tech University, 2012.

[3] Zhang X, Li Q, Lin Z. E-Commerce Education in China[J]. Journal of Electronic Commerce in Organizations, 2007, 3(3):1-17.

[4] Li Y. Analysis on Financial Management of E-commerce Enterprise[C]// International Conference on Education, Sports, Arts and Management Engineering. 2017.

[5] Pan C Y. A Probe into the Actual Ecological System of Modern E-commerce Business Education[J]. Value Engineering, 2017.

[6] Dabbagh R A. E-business: Concepts and context with illustrative examples of e-business and e-commerce in education[J]. 2011.

[7] Gorla N, Chinta R, Chinta R. Business-to-business e-commerce adoption: An empirical investigation of business factors[M]. Kluwer Academic Publishers, 2017.

[8] Dabbagh R A. E-business: Concepts and context with illustrative examples of e-business and e-commerce in education[J]. 2011.

[9] Fang M. Toward the Deep Integrated Development of the Information-based Society-Looking at "Internet Plus" from the Perspective of the Transformation of Civilization[J]. Journal of Management Studies, 2015, 30(6):975-995.

[10] Xiong W, Xiang F, Zhao Z, et al. Influence of Internet plus to International Business Development[J]. American Journal of Industrial \& Business Management, 2016, 6(4):541-549. 